\title{
Study on the Construction of Assessment Mechanism Based on Eco-Environment Quality Improvement Targets
} \author{
$\mathrm{Na} \mathrm{LI}{ }^{1}$, Zhanfeng DONG ${ }^{1, *}$, and Rui HU ${ }^{1, *}$ \\ ${ }^{1}$ Chinese Academy for Environmental Planning, Beijing, 100021, China \\ ${ }^{2}$ School of Environment, Beijing Normal University, Beijing, 100875, China \\ ${ }^{3}$ China Agricultural University, Beijing, 100083, China \\ ${ }^{4}$ Southwest university of science and technology, Mianyang, 621000, China
}

Chunxu HAO ${ }^{1}$, Chazhong $\mathrm{GE}^{1}$, Jinglan $\mathrm{QIN}^{2}$, Quan ZHOU ${ }^{1}$, Chen PENG ${ }^{1}$, Xueyan $\mathrm{GUO}^{3}$, Zhuming LIANG ${ }^{4}$, Aiyu QU ${ }^{1}$,

\begin{abstract}
The environmental protection target responsibility system and the appraisal system is a major measure in our country's environmental protection system. The existing ecological environmental assessment forms are diverse, various, but lack of overall planning, ecological environment quality guidance is not prominent. There are problems such as immature evaluation mechanism and incomplete design of indicator design system. This research system evaluates the assessment system in the existing environmental protection system, accelerates the overall integration, takes the environmental performance as the basic direction, takes the environmental quality goal improvement as the main line, formulates and implements a set of environmental quality target assessment index system with scientific, incentive, pertinence and maneuverability, conforms to the national conditions of our country, scientifically evaluates the effect of environmental management, and realizes the index management of environmental protection.
\end{abstract}

\section{Introduction}

The 18th CPC National Congress proposed that we should move faster to set up a system for ecological progress. Resource consumption, environmental damage and ecological benefits should be covered by the system of standards for evaluating economic and social development, and related goals, evaluation methods and reward and punishment mechanisms should be adopted in keeping with the need of promoting ecological progress. ${ }^{[1]}$ Environmental quality assessment is an integral part of environmental protection and a necessary and scientific measure taken by the government to improve environmental quality ${ }^{[2]}$. The assessment of eco-environmental quality targets is about the environmental management system in which the superior environmental protection department quantifies and evaluates the progress of the regional eco-environment quality improvement targets driven by local performance, involving such sectors as air, water, soil, solid waste. The competent authorities of environmental protection have pushed forward evaluation of pollution reduction, the total amount of major pollutants, and the water quality objectives in key basins. Other authorities outside the sector such as Organization Department of the Central Committee, Supervision Bureau, Forestry and Water Conservancy sectors also incorporate environmental protection into their evaluation. Existing substantial, complicated and overlapped assessments are unsystematic and burdensome at the cost of administrative resources and bring huge pressure to actors of assessment and local governments ${ }^{[3-5]}$.

Eco-environmental quality target assessment is effective in integrating the existing environmental protection assessment system, saving administrative resources, and improving the efficiency of environmental management as a useful tool. Government is transforming its eco-environmental protection orientation from effect to efficiency and quality [6]. The assessment of eco-environmental quality targets is essential for the eco-environment management transformation as it can lead to greater efficiency and fine management. Y.Z. Guan (2008) believes that it's government's assessment target to reduce environmental pollution while a strict assessment system for emission reduction is the basis for government to fulfill its responsibility for environmental protection ${ }^{[7]}$. According to D.W. Jiang (2009), it is of great significance to incorporate soil and water conservation into the government evaluation system as it is necessary for a government ruled by law and an effective method to put in place performance assessment requirements ${ }^{[8]}$. J.F. Li (2011) holds that environmental quality assessment is one of the necessary and scientific measures taken by the government to improve environmental quality [2]. The rollout of eco-environment quality target assessment can provide specific input and advice for the development of national or local environmental policies and environmental management so as to avoid faults in environmental policies. At present, the lack of eco-

\footnotetext{
Corresponding author: haocx@caep.org.cn
} 
environment quality assessment in China is standing in the way of more scientific environmental management. The integration of environmental and economic and social policies still has a way to go, so it is an inevitable problem for China going forward to go further in the integration ${ }^{[9]}$. Assessment of eco-environment quality target can figure out the main factors affecting performance of environmental management, thus contributing to scientifically-grounded and effective decisions with all aspects into consideration.

\section{Progress and Effect of Eco- environmental Quality Improvement Target Assessment}

The assessment based on ecological environment quality has taken shape, and plays a guiding role in the improvement of eco-environment quality. As the total emission of major pollutants is overtaken by the environmental quality as the constraint, the ecoenvironmental quality indicators are gaining a bigger share in the eco-environment protection assessments such as evaluation of implementing Ten Prevention and Control Measures for Air Pollution, Ten Prevention and Control Measures for Water Pollution, Ten Prevention and Control Measures for Soil Pollution, obligatory targets assessment of environmental protection, and the final assessment of the Five-Year Plan for National Environmental Protection etc. The assessments related to eco-environment quality have also been incorporated into the government work assessment system with increasing score and share. In addition, the ecoenvironment protection is gradually included into the performance assessment system of leading cadres. In this way, the assessment results of the eco-environment quality targets are tied to those of party and government bodies and cadres. It is gradually joining other systems such as responsibility system and accountability system for environmental protection as vital measures and means for ecological progress and higher ecoenvironment quality.

\section{Problems in Eco-environmental Quality Improvement Target Assessment}

1) The overwhelming assessments with burdensome procedures lead to high administrative cost as many human, material and financial resources are invested. 2) The assessment is not fully eco-environmental quality oriented as indicators such as achievement of ecoenvironmental tasks and emission reduction of major pollutants etc. still take a big part in the existing ecoenvironmental assessment indicator system. 3) The assessment objects are not comprehensive, failing to completely act on the policies of co-responsibility of the party and administration and two duties for one post, so the responsibilities of environmental protection are hard to be assigned to individuals. 4) The role of actors for assessment is not clearly defined. In practice, it seems eco-environment departments are mainly responsible for assessment and accountability. It may be reduced to the department assessment. 5) Incentive measures are absent to support the assessment, thus hard to give a clear message of stimulation to relevant departments and government, let alone the motivation mechanism. 6) The assessment results are not made full use. The assessment results of eco-environmental protection are not tied to the reward, punishment and promotion of cadres as mandatory indicator. It can play a bigger role.

\section{Construction of Assessment Mechanism Based on Eco-Environment Quality Targets}

\subsection{Idea}

The assessment system based on eco-environment quality targets shall be established with environmental quality improvement as the core and progress of environmental quality indicators as mandatory requirement. It should orient toward solving outstanding environmental problems. Efforts shall be made to coordinate the assessment by reforming total emission reduction evaluation and innovating the way we work. Assessment needs to be tied to rewards and punishments. The work must be carried out in greater unison between the higher and lower levels of government to improve efficiency. These efforts can lay the foundation for achieving the relevant targets. The construction of the assessment system based on eco-environment quality targets can follow two steps:

The first step is to keep the existing assessments unchanged such as implementing Ten Prevention and Control Measures for Air Pollution, Ten Prevention and Control Measures for Water Pollution, Ten Prevention and Control Measures for Soil Pollution and obligatory targets assessment of environmental protection. These include the progress in air quality, water environment quality, soil environment quality, the key tasks of air, water and soil pollution prevention and control, as well as total emission reduction of chemical oxygen demand, ammonia nitrogen, sulfur dioxide and nitrogen oxide. Coordination and division of labor with individual responsibility shall go hand in hand. We need do a good job in coordinating various aspects especially in unified assessment time and methods to reduce repetitive work and improve efficiency. In addition, environmental quality shall always be at core, so the assessment results of environmental quality shall take precedence over those of total emission reduction, air and water pollution prevention and control key tasks.

The second step is to integrate the existing assessment systems such as implementing Ten Prevention and Control Measures for Air Pollution, Ten Prevention and Control Measures for Water Pollution, Ten Prevention and Control Measures for Soil Pollution and obligatory targets assessment of environmental protection into a set of unified indicator system, covering indicators related to water, air, soil, ocean etc.. 


\subsection{Assessment Methods}

Primary actors of assessment. It is suggested that the environmental protection authorities set up a comprehensive coordination office to take the lead in implementing the assessment. The assessment of ecoenvironmental quality targets involves many departments within the environmental protection sector. They need to work together with coordinated arrangement. These efforts allow easier access to assessment data and materials, make assessment organization convenient and help include the assessment results into the government assessment system. In addition, third parties can be introduced to organize some indicators' assessment, including the development of evaluation standards or contents. The combination of internal and third-party ways can make evaluation more neutral and engage broader public in the process.

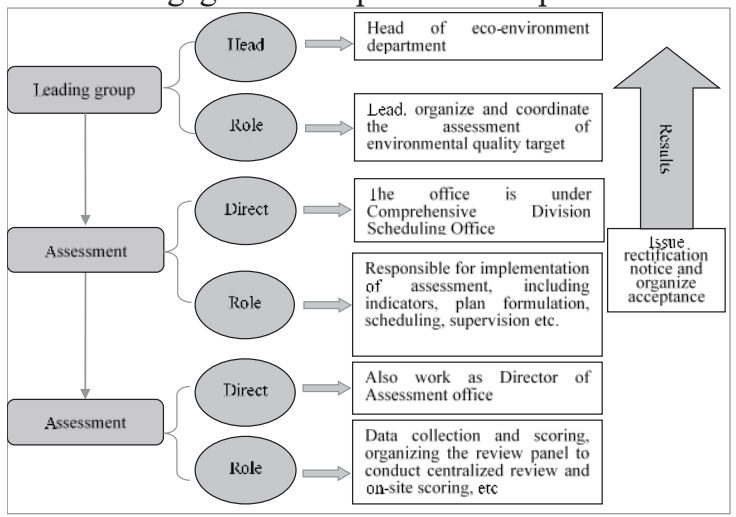

Fig. 1. Organization of eco-environment quality target assessment.

The objects of assessment are 31 provincial (district, city) governments and Xinjiang Production and Construction Corps.

Assessment content shall include four aspects: quality indicators of air, water, soil, ocean, noise, solid waste and other elements, total pollutant control, ecological environment, rural environmental protection, environmental safety, implementation of environmental protection system, public satisfaction and other ecoenvironmental system construction indicators. Meanwhile, in light of varying resource endowment and regional difference in China, assessment system shall be differentiated to consider both final results and progressive results.

Assessment methods. The provincial level works as the primary actors of assessment in the way of selfexamination and being reviewed by the state. The progress of environmental quality indicators shall be jointly determined by the Ministry of Ecological Environment and relevant departments on the basis of the monitoring data, taking into account the major influencing factors and how environmental monitoring quality system operates. The progress of the total emission reduction indicator and the key tasks of air, water and soil pollution prevention and control shall also be jointly determined by the Ministry of Ecological Environment and relevant departments after examination. 1) Provincial self-examination. Each province (district, city) shall, in accordance with the assessment regulations, organize self-examination on how the regulations regarding air, water and soil have been followed through in its own administrative region, and total emission reduction, which creates the self-examination report. 2) Analysis and review. The Ministry of Ecological Environment, together with relevant departments, shall review the self-examination reports submitted by each province (district or city) in accordance with the assessment regulations and division of labor of each department, and determine the list of provinces (districts or cities) for spot check considering the progress of environmental quality indicators and supervision. 3) Spot check. The Ministry of Ecological Environment, together with relevant departments, shall organize data check, meeting review and on-site spot check for the provinces (district, city) on the list, and thus generate a report based on their self-examination reports, written review opinions, environmental protection supervision, daily supervision and inspection, pollution source supervision monitoring and automatic online monitoring. Among them, macro new pollutant emissions, emission reduction beyond key projects, construction and operation of key projects, etc. shall be the focus of recheck for total emissions reduction. 4) Determine the assessment results. The results graded by hundred-mark system should be divided into four grades: excellent, good, qualified and unqualified considering the progress of obligatory targets. According to the relevant assessment regulations, the Ministry of Ecological Environment should summarize the spot check results of the implementation of above-mentioned regulations of air, water and soil, and finalize the assessment results.

\subsection{Assessment Index System}

The assessment index system of ecological environment quality shall be established under thematic framework and aim at higher eco-environment quality, including three first-level indexes, namely ecological environment quality, rural and ecological protection, and the implementation of environmental protection system. Among them, the ecological environment quality includes 5 secondary indicators, air quality, water environment quality, soil environment quality, noise pollution prevention and control, and solid waste pollution treatment. Rural and ecological protection is composed of 3 secondary indicators, ecological resources, rural environmental protection and environmental safety. The implementation of environmental protection system includes one third-level indicator, namely the construction of environmental protection system.

Table 1. Assessment index system of ecological environment quality targets and weight.

\begin{tabular}{|c|c|c|c|c|}
\hline No. & $\begin{array}{c}\text { First-level } \\
\text { index }\end{array}$ & $\begin{array}{c}\text { Secondary } \\
\text { index }\end{array}$ & $\begin{array}{c}\text { Third-level } \\
\text { index }\end{array}$ & Source \\
\hline 1 & $\begin{array}{c}\text { Ecological } \\
\text { environme } \\
\text { nt quality }\end{array}$ & $\begin{array}{c}\text { Air } \\
\text { quality }\end{array}$ & $\begin{array}{c}\text { Air quality } \\
\text { compliance } \\
\text { index }\end{array}$ & $\begin{array}{c}\text { Self- } \\
\text { report and } \\
\text { examinati } \\
\text { on }\end{array}$ \\
\hline
\end{tabular}




\begin{tabular}{|c|c|c|c|}
\hline 2 & & $\begin{array}{c}\text { PM2.5 } \\
\text { pollution } \\
\text { improveme } \\
\text { nt index }\end{array}$ & $\begin{array}{c}\text { Self- } \\
\text { report and } \\
\text { examinati } \\
\text { on }\end{array}$ \\
\hline 3 & & $\begin{array}{c}\text { Achieveme } \\
\text { nt of tasks } \\
\text { required in } \\
\text { Ten } \\
\text { Prevention } \\
\text { and Control } \\
\text { Measures } \\
\text { for Air } \\
\text { Pollution }\end{array}$ & $\begin{array}{c}\text { Entrust } \\
\text { third- } \\
\text { party } \\
\text { organizati } \\
\text { on }\end{array}$ \\
\hline 4 & \multirow{4}{*}{$\begin{array}{c}\text { Water } \\
\text { environme } \\
\text { nt quality }\end{array}$} & $\begin{array}{c}\text { River } \\
\text { monitoring } \\
\text { section } \\
\text { water } \\
\text { function } \\
\text { area } \\
\text { compliance } \\
\text { rate } \\
\end{array}$ & $\begin{array}{l}\text { Self- } \\
\text { report and } \\
\text { examinati } \\
\text { on }\end{array}$ \\
\hline 5 & & $\begin{array}{l}\text { Good rate } \\
\text { of main } \\
\text { lakes and } \\
\text { reservoirs } \\
\text { water } \\
\text { quality }\end{array}$ & $\begin{array}{l}\text { Self- } \\
\text { report and } \\
\text { examinati } \\
\text { on }\end{array}$ \\
\hline 6 & & $\begin{array}{l}\text { Water } \\
\text { quality } \\
\text { qualified } \\
\text { rate of } \\
\text { centralized } \\
\text { drinking } \\
\text { water } \\
\text { source }\end{array}$ & $\begin{array}{l}\text { Self- } \\
\text { report and } \\
\text { examinati } \\
\text { on }\end{array}$ \\
\hline 7 & & $\begin{array}{c}\text { Achieveme } \\
\text { nt of tasks } \\
\text { required in } \\
\text { Ten } \\
\text { Prevention } \\
\text { and Control } \\
\text { Measures } \\
\text { for Air } \\
\text { Pollution }\end{array}$ & $\begin{array}{c}\text { Entrust } \\
\text { third- } \\
\text { party } \\
\text { organizati } \\
\text { on }\end{array}$ \\
\hline 8 & \multirow[b]{2}{*}{$\begin{array}{c}\text { Soil } \\
\text { environme } \\
\text { nt quality }\end{array}$} & $\begin{array}{l}\text { Qualified } \\
\text { rate of soil } \\
\text { environmen } \\
\text { tal quality }\end{array}$ & $\begin{array}{c}\text { Self- } \\
\text { report and } \\
\text { examinati } \\
\text { on }\end{array}$ \\
\hline 9 & & $\begin{array}{c}\text { Achieveme } \\
\text { nt of tasks } \\
\text { required in } \\
\text { Ten } \\
\text { Prevention } \\
\text { and Control } \\
\text { Measures } \\
\text { for Soil } \\
\text { Pollution }\end{array}$ & $\begin{array}{c}\text { Entrust } \\
\text { third- } \\
\text { party } \\
\text { organizati } \\
\text { on }\end{array}$ \\
\hline 10 & \multirow{2}{*}{$\begin{array}{l}\text { Noise } \\
\text { pollution } \\
\text { prevention } \\
\text { and } \\
\text { control }\end{array}$} & $\begin{array}{l}\text { Road traffic } \\
\text { noise }\end{array}$ & $\begin{array}{c}\text { Self- } \\
\text { report and } \\
\text { examinati } \\
\text { on }\end{array}$ \\
\hline 11 & & $\begin{array}{l}\text { Regional } \\
\text { environmen } \\
\text { tal noise }\end{array}$ & $\begin{array}{c}\text { Self- } \\
\text { report and } \\
\text { examinati } \\
\text { on }\end{array}$ \\
\hline 12 & $\begin{array}{c}\text { Solid } \\
\text { waste } \\
\text { pollution }\end{array}$ & $\begin{array}{c}\text { Harmless } \\
\text { treatment } \\
\text { rate of }\end{array}$ & $\begin{array}{c}\text { Self- } \\
\text { report and } \\
\text { examinati }\end{array}$ \\
\hline
\end{tabular}

\begin{tabular}{|c|c|c|c|c|}
\hline & & treatment & $\begin{array}{l}\text { household } \\
\text { waste }\end{array}$ & on \\
\hline 13 & & & $\begin{array}{c}\text { Industrial } \\
\text { solid waste } \\
\text { disposal } \\
\text { rate }\end{array}$ & $\begin{array}{c}\text { Self- } \\
\text { report and } \\
\text { examinati } \\
\text { on }\end{array}$ \\
\hline 14 & & \multirow{2}{*}{$\begin{array}{c}\text { Heavy } \\
\text { metal } \\
\text { pollution } \\
\text { treatment }\end{array}$} & $\begin{array}{c}\text { Emission of } \\
\text { heavy } \\
\text { metal } \\
\text { pollutants } \\
\text { in key areas }\end{array}$ & $\begin{array}{l}\text { Self- } \\
\text { report and } \\
\text { examinati } \\
\text { on }\end{array}$ \\
\hline 15 & & & $\begin{array}{c}\text { Emission of } \\
\text { heavy } \\
\text { metal } \\
\text { pollutants } \\
\text { in non-key } \\
\text { areas }\end{array}$ & $\begin{array}{l}\text { Self- } \\
\text { report and } \\
\text { examinati } \\
\text { on }\end{array}$ \\
\hline 16 & \multirow{3}{*}{$\begin{array}{l}\text { Rural and } \\
\text { ecological } \\
\text { protection }\end{array}$} & $\begin{array}{c}\text { Ecological } \\
\text { resources }\end{array}$ & $\begin{array}{l}\text { Change of } \\
\text { ecological } \\
\text { resources }\end{array}$ & $\begin{array}{c}\text { Entrust } \\
\text { third- } \\
\text { party } \\
\text { organizati } \\
\text { on } \\
\end{array}$ \\
\hline 17 & & $\begin{array}{c}\text { Rural } \\
\text { environme } \\
\text { ntal } \\
\text { protection }\end{array}$ & $\begin{array}{c}\text { Rural } \\
\text { environmen } \\
\text { tal } \\
\text { protection }\end{array}$ & $\begin{array}{c}\text { Entrust } \\
\text { third- } \\
\text { party } \\
\text { organizati } \\
\text { on }\end{array}$ \\
\hline 18 & & $\begin{array}{c}\text { Environm } \\
\text { ental } \\
\text { safety }\end{array}$ & $\begin{array}{c}\text { Environme } \\
\text { ntal } \\
\text { accident } \\
\text { index }\end{array}$ & $\begin{array}{c}\text { Self- } \\
\text { report and } \\
\text { examinati } \\
\text { on }\end{array}$ \\
\hline 19 & $\begin{array}{l}\text { Implemen } \\
\text { tation of } \\
\text { environme }\end{array}$ & $\begin{array}{l}\text { Constructi } \\
\text { on of } \\
\text { environme }\end{array}$ & $\begin{array}{c}\text { System } \\
\text { implementa } \\
\text { tion }\end{array}$ & $\begin{array}{c}\text { Entrust } \\
\text { third- } \\
\text { party } \\
\text { organizati } \\
\text { on } \\
\end{array}$ \\
\hline 20 & $\begin{array}{c}\text { ntal } \\
\text { protection } \\
\text { system }\end{array}$ & $\begin{array}{c}\text { ntal } \\
\text { protection } \\
\text { system }\end{array}$ & $\begin{array}{c}\text { Public } \\
\text { satisfaction }\end{array}$ & $\begin{array}{c}\text { Entrust } \\
\text { third- } \\
\text { party } \\
\text { organizati } \\
\text { on }\end{array}$ \\
\hline
\end{tabular}

\subsection{Application of Assessment Results}

The assessment results of eco-environment quality targets will be applied to evaluate the achievements and annual performance of the cadres, and help select the officials. Organization Department shall set up assessment files of eco-environment quality targets of leading cadres, and take results as part of performance for leading bodies and cadres. Those who fail the assessment shall be criticized in a circulated notice by Assessment Office, and head of the unqualified organization shall not be promoted or in important positions within two years, and shall make a public apology on the main media. In the case that an organization unqualifies for two years in a row, its head and the person in charge shall be changed positions or transferred to non-leading posts. The organizations whose assessment score ranks last in each category and is lower than $70 \%$ of the total points shall receive a "yellow card" warning from the assessment leading group. Those whose assessment score ranks last in each category and is lower than $80 \%$ of the total points shall face a conversation of admonition with their heads and 
persons in charge. The government will give a notice of commendation to the examinees with excellent performance and who have won the progress award. For those who are unqualified, warned with "yellow card" and have many problems exposed in the assessment, the Assessment Office shall issue a notice of rectification to them to improve within a time limit. Upon the completion, the Assessment Office shall organize the verification and report the acceptance results to the assessment leading group. The assessed organizations can hold accountable who to blame inside them based on the results and division of responsibilities.

\section{Policy Suggestions}

\subsection{Speed up the Enactment and Implementation of the Assessment System of Eco-environment Quality Targets}

First, we should step up the legal construction of ecoenvironment quality target assessment. In this way, it can place tighter constraints on environmental management and strengthen the assessment means, creating necessary legal underpinning for the assessment of ecoenvironment quality targets on an institutionalized basis going forward. Second, we shall develop unified rules and regulations for eco-environment quality target assessment. The Guideline for the Assessment Method of Eco-environment Quality Target can be issued to clarify the concept, implementation scope, steps, primary actors, operation procedures, index system, supervision and balance, and application of assessment results. By doing the above, the assessment can be carried out in a standardized, coordinated and orderly manner under the constraint of a unified system. Third, we shall build on what we have done previously. It is necessary to combine with previous construction of regional environmental management system, regional environmental safety evaluation, local government target-oriented responsibility assessment system for environment and performance assessment system. These efforts can ensure systematic progress of the assessment in a coordinated manner.

\subsection{Establish Robust Long-term Mechanisms for Eco-environment Quality Target Assessment}

First, we should establish an effective mechanism for eco-environment quality target assessment in line with international standards. We shall learn and summarize the research basis and best practices of other countries in the field, and draw on foreign experience by greater cooperation with international organizations. In this way, the mechanism can be much closer to international practice and allow a more scientific, efficient and standardized environmental protection assessment. Second, we shall encourage to engage diversified actors in the assessment. The combination of independent assessment, joint assessment of multiple departments and the third-party assessment can create an effective, objective and reasonable mechanism that features assessment procedures, index system, method, standards and supervision, etc. It can offer a platform for the cooperation across regions and localities in environmental protection and ensure the fairness of the assessment results. Third, we should move faster to establish a real-time long-term mechanism for the assessment. There is a certain time lag in the current environmental assessment because the official data, basis of indicators evaluation, is time sensitive. Therefore, it is suggested to speed up the data collection, strictly control the data quality, realize the real-time assessment of the current year in the future, evaluate the timeliness of the results application. By doing these, data collection can better play its role to provide support for the environmental management in real time.

\subsection{Explore to Establish and Improve Evaluation Methods and Index System of Eco-environment Quality Target}

First, we shall build and improve the assessment index system of ecological environment quality target. On the basis of facts and data, a set of scientific, motivating, viable and simple assessment index system shall be established to reflect the current management. It shall be able to realize the index management of the environment and provide a quantitative evaluation scale for the assessment, so as to evaluate the effect of environmental management scientifically. Second, we should strengthen the use of information technology and establish a data center for the assessment. It is suggested to take more steps for the establishment of national data center or database of the target assessment. The jointly built and sharing information platform can be set up by collection, summary, storage and transfer of the data obtained from various regions, environmental protection departments, water conservancy departments, land and resources management departments, forestry departments, statistical departments and other departments etc. The data space-time information needed by assessment shall be available for query. It can help the government at all levels gear up for ecological environment quality target assessment in the next step.

\subsection{Make Further Progress in Trials of Eco- environment Quality Target Assessment}

First, we shall launch trials of eco-environment quality target assessment. It requires to reflect national reality and take a deep dive into how to proceed with the trials in different cities gradually. We should propose a sound and feasible implementation plan for eco-environment quality target assessment, which shall be more relevant to China's reality in environment management and systems. The plan should be implemented step by step and with emphasis after being justified and piloted. Second, all departments shall coordinate with each other and have clearly defined roles. Launching the assessment needs the communication and coordination of all departments, especially in the process of data collection. For some tricky data, the coordination among the 
evaluated areas, Statistics Bureau, National Development and Reform Commission, Finance Bureau etc. can come into play. The assessment also requires human, material and financial support, so it is necessary to guarantee the fund and talent pipeline.

\section{References}

1. H.Q. Jiang, J.N. Wang, X. Cheng. Establishment and improvement of eco-environment performance evaluation and accountability system. Environmental Protection Science,41(05),4348(2015)

2. J.F. Li. Study on the construction of environmental quality assessment system in Henan Province. (Zhengzhou University, 2011)

3. Q. Liu. Environmental assessment should highlight the weight of environmental quality improvement. China Environmental News, 003,04-07 (2017)

4. X.T. Li. Study on performance evaluation and improvement strategies of environmental governance in Beijing-Tianjin-Hebei region. (Yanshan University, 2018)

5. Y.N. Lu. Study on performance evaluation and accountability system of ecological civilization. Modern Economic Information, 24,92(2017)

6. L.Y. Zhang, Y. Qi, X.Q. Mao, M.J. Gong. From quantitative to qualitative assessment: Analysis on the transformation of government environmental protection assessment. China Population, Resources and Environment, 28 (10), 105-111(2018)

7. Y.Z. Guan. Thoughts and suggestions on establishing the accountability system of government pollution reduction. Xiamen Science and Technology, 01,17-20(2008)

8. D.W. Jiang. Establishment of performance evaluation system and monitoring evaluation system of local governments on Soil and water conservation. China Soil and Water Conservation, 03,1-4 (2009)

9. Y. Wu. Study on the assessment system of environmental protection of Chinese government. (Hunan Normal University, 2018) 